\title{
PALMARIS LONGUS ABSENT IN ONE IDENTICAL TWIN: A CASE REPORT
}

\author{
Nikola Vučinić ${ }^{1}$, Mirela Erić ${ }^{1}$, Lovorka Grgurević ${ }^{2}$, Ivo Dumić-Čule ${ }^{3}$ and Nino Tičinović ${ }^{3}$ \\ ${ }^{1}$ Department of Anatomy, Faculty of Medicine, University of Novi Sad, Novi Sad, Serbia; \\ ${ }^{2}$ Laboratory for Mineralized Tissues, School of Medicine, University of Zagreb, Zagreb, Croatia; \\ ${ }^{3}$ Department of Diagnostic and Interventional Radiology, Dubrava University Hospital, Zagreb, Croatia
}

SUMMARY - Palmaris longus is a very variable muscle in the human body, but it is often used as an applicable tendon graft. We report on differences between one pair of identical twins regarding the existence of the palmaris longus, which were detected accidentally during examination of the presence/ absence of this muscle in Caucasian population. In one of the twins, the palmaris longus was present at both forearms, while the other twin was lacking this muscle at both forearms. On search of the available literature, we found no articles about distinctions in the presence or absence of the palmaris longus in twins.

Key words: Tendons; Twins, monozygotic; Muscle, skeletal; Forearm

\section{Introduction}

Palmaris longus (PL) is a thin muscle which originates from the medial epicondyle by a short belly, located superficially in the middle of the anterior aspect of the forearm. The long tendon crosses the flexor retinaculum and becomes incorporated into palmar aponeurosis ${ }^{1,2}$. The median nerve innervates the PL and the muscle performs weak flexion in the wrist. The PL is variable in number and form ${ }^{1}$.

During examination of the PL existence in 300 Caucasian subjects, we found differences in the presence/absence of the PL in one pair of twins (two girls). To the best of our knowledge, distinctions in the existence of this muscle in twins have not been described in the literature.

\section{Case Report}

This study was approved by the Independent Ethics Committee of the Faculty of Medicine in Novi

Correspondence to: Nikola Vučinic, $M D$, Department of Anatomy, Faculty of Medicine, University of Novi Sad, Hajduk Veljkova 3, 21000 Novi Sad, Serbia

E-mail: nikola.vucinic@mf.uns.ac.rs

Received June 19, 2017, accepted November 27, 2017
Sad. In our sample that included 300 subjects of Caucasian population, the existence of the PL tendon was established on both forearms using several clinical tests. A standard test (Schaeffer's test) was first used in the detection of the PL tendon. In cases where visualization or palpation was not clear, two other tests were performed to verify its absence. We used the following tests:

- standard test: the subject opposes the thumb to the little finger and flexes the wrist ${ }^{3}$;

- Thompson's test: the subject makes a fist, then flexes the wrist while the thumb is opposed and flexed over the fingers ${ }^{4}$; and

- Pushpakumar's 'two-finger sign' method: the subject completely extends the index and middle fingers, the wrist and other fingers being in flexed position, and the thumb is completely opposed and flexed ${ }^{5}$.

In the total sample, we had one pair of identical twins. These were girls aged 19. Both twins were righthanded. Examining the existence of the PL muscle in both twins, we found diametric differences. In one of the twins, the PL was present bilaterally (Fig. 1), whereas the other twin was bilaterally without this muscle (Fig. 2). 


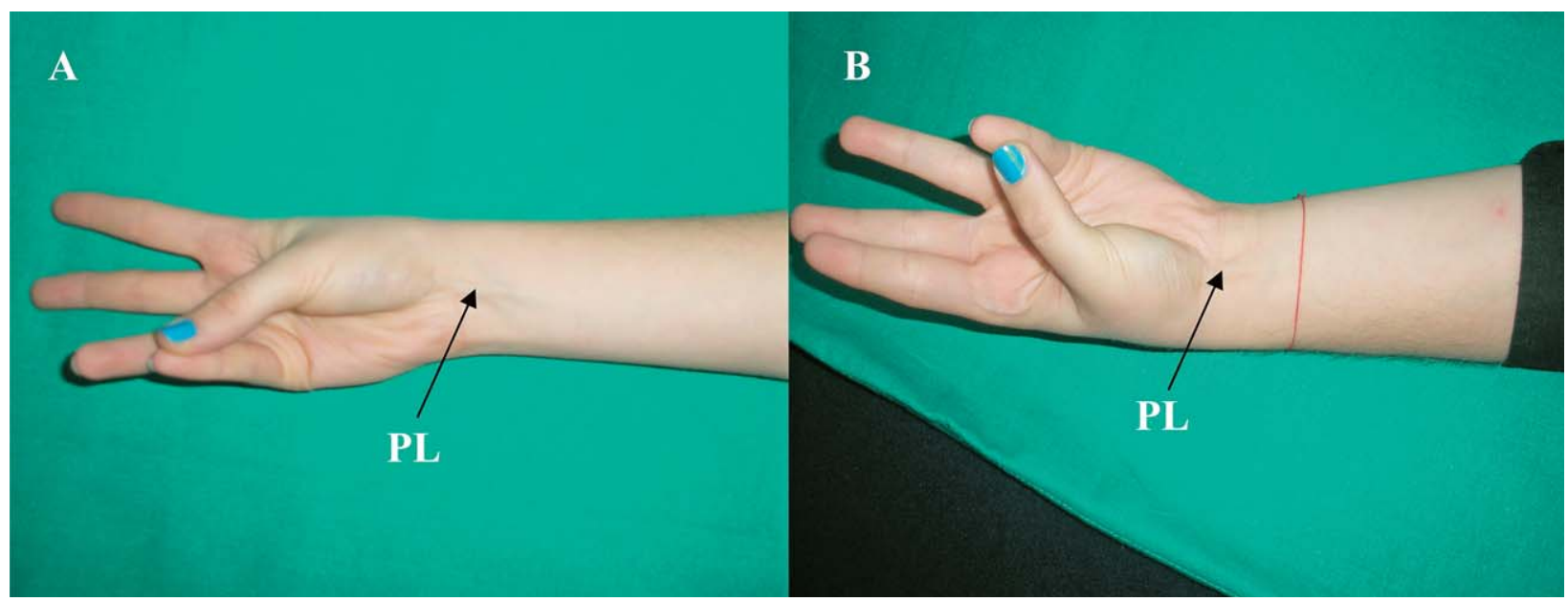

Fig. 1. Palmaris longus present in one of the twins: right forearm $(A)$ and left forearm (B).

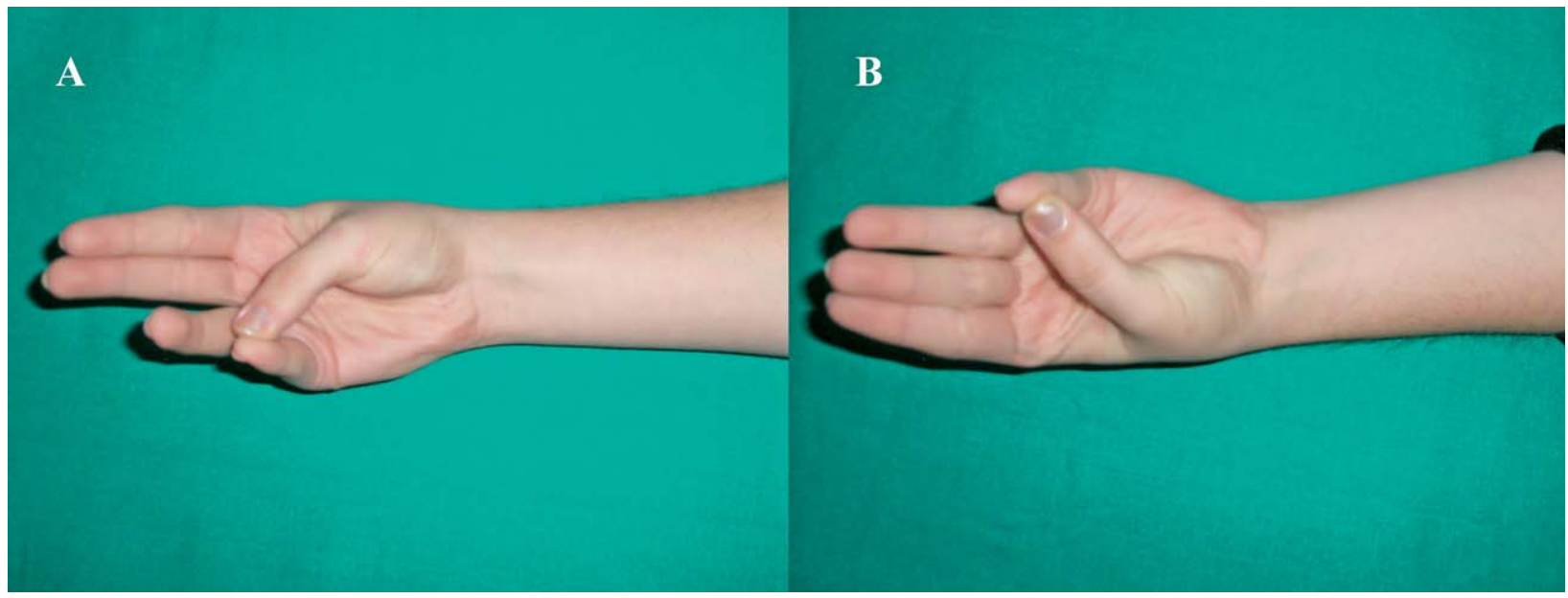

Fig. 2. Palmaris longus absent in the other of the twins: right forearm $(A)$ and left forearm (B).

The differences in the presence/absence of the PL muscle in these twins were well detected by the standard test. The twins had full mobility of hand joints and no previous injury, disease or abnormality of upper limbs.

\section{Discussion}

The palmaris longus is very often completely absent $^{1}$. Phylogenetically, this muscle is a degenerate flexor of the metacarpophalangeal joint ${ }^{2}$. The frequency of PL absence in hand surgery textbooks is approximately $15 \% \%^{6,7}$. Moreover, the percentage of its absence varies among different ethnic groups, from $0.6 \%$ in the Korean population to $63.9 \%$ in the Turkish popula- tion $^{8,9}$. Different anatomic anomalies could be in correlation with PL absence ${ }^{10,11}$.

This muscle has a great importance in transplantation because of its little functional use in the hand. Surgeons point out that the PL tendon graft is the best option in tendon reconstruction, in particular for replacement of the superficial and deep flexors of the fingers and the flexor pollicis longus tendon. The presence of the tendon of this muscle in the wrist determines the localization of the median nerve in surgical procedures.

The absence of the PL muscle is strictly a hereditary characteristic. The PL muscle is an inherited autosomal dominant trait. The absence of the $\mathrm{PL}$ muscle is probably connected with a single dominant 
gene (which shows incomplete penetration and variable expressivity), and/or absence is due to the effects of mutations ${ }^{12}$.

Thompson et al. ${ }^{4}$ found that the inheritance of the PL is of similar nature as the inheritance of polydactyly. Parents with unilateral absence may have children with a lack of the muscle in one or both arms, whereas parents with the bilateral lack of the muscle can have children with a lack of the muscle in one hand.

It is presumed that identical twins share the same genome and have the same hereditary endowments in all circumstances. Hall ${ }^{13}$ claims that the mechanism in separation of blastomeres, which leads to identical twinning, could be some genetic changes that distinguish one cell from another. 'Identical' twinning is caused by the non-identity of the early blastomeres, concludes the same author. According to this rule, each member of a pair of monozygotic twins can develop very differently from the other twin. These 'discordant identical twins' are contrary to assertion that each of the identical twins will have the same development.

Congenital muscle absence of the anterior compartment of the legs in a sister of identical twins has been reported and it was the first one in the literature ${ }^{14}$. During surgery, it was revealed that the muscles of the anterior compartment of the leg were completely replaced by fat tissue, but the deep peroneal nerve was ordinary.

Stevens et al. ${ }^{15}$ have described Poland's syndrome in one of the identical female twins, whereas the other twin was normal (this syndrome is manifested by the absence of the pectoralis major muscle with symbrachydactyly of the right upper extremity). These authors claim that their twin case provides strong evidence that the condition is not determined by gene transmission.

The case described herewith is very rare and presents the first-described distinction in the presence or absence of the PL in twins. It is known that variations often occur in one of the paired organs, muscles of the body, but not in the other, and this suggests that a genetic trait may not necessarily be bilateral ${ }^{16}$. A genetic trait is probably determined by the interaction of an individual's genes and developmental environment in the uterus. We believe that this rule, which refers to individuals, also applies to differences between identical twins and our case of the absent PL in one identical twin confirms it.

\section{References}

1. Erić M, Krivokuća D, Savović S, Lekšan I, Vučinić N. Prevalence of the palmaris longus through clinical evaluation. Surg Radiol Anat. 2010;32:357-61. https://doi.org/10.1007/s00276-009-0573-0

2. Standring S. Gray's Anatomy. 39 $9^{\text {th }}$ edn. Edinburgh: Elsevier Churchill Livingstone; 2005.

3. Sebastin SJ, Lim AY. Clinical assessment of absence of the palmaris longus and its association with other anatomical anomalies - a Chinese population study. Ann Acad Med Singapore. 2006;35:249-53.

4. Thompson JW, McBatts J, Danforth CH. Hereditary and racial variations in the musculus palmaris longus. Am J Phys Anthrop. 1921;4:205-20.

5. Pushpakumar SB, Hanson RP, Carroll S. The 'two finger' sign. Clinical examination of palmaris longus (PL) tendon. $\mathrm{Br} \mathrm{J}$ Plast Surg. 2004;57:184-5. https://doi.org/10.1016/j.bjps.2003.11.024

6. Saldana MJ. Primary extensor tendon grafts in zones 5 to 7. In: Blair WE, editor. Techniques in Hand Surgery. Baltimore: Williams \&Wilkins; 1996: p. 587.

7. Smith P. Injury. In: Smith P, editor. Lister's The Hand - Diagnosis and Indications. London: Churchill Livingstone; 2002: p. $1-140$.

8. Ahn DS, Yoon ES, Koo SH, Park SH. A prospective study of the anatomic variations of the median nerve in the carpal tunnel in Asians. Ann Plast Surg. 2000;44:282-7.

9. Ceyhan O, Mavt A. Distribution of agenesis of palmaris longus muscle in 12-18 years old age groups. Indian J Med Sci. 1997;51:156-60.

10. Agarwal P. Absence of the palmaris longus tendon in Indian population. Indian J Orthop. 2010;44(2):212-5. https://doi. org/10.4103/0019-5413.61863

11. Tan J, Oh L, Louis D. Variations of the flexor digitorum superficialis as determined by an expanded clinical examination. J Hand Surg Am. 2009;34(5):900-6. https://doi.org/10.1016/j. jhsa.2009.01.002

12. Vučinić N, Erić M, Savić M. How often absence of palmaris longus and functional deficiency of flexor digitorum superficialis occurs? Acta Orthop Belg. 2016;82:405-15.

13. Hall J. Twins and twinning. Am J Med Genet. 1996;61:202-4. https://doi.org/10.1002/(SICI)1096-8628(19960122)61:3< 202::AID-AJMG2>3.0.CO;2-W

14. Ohno K, Monji J, Sasaki T, Inoue K, Shiono H. Congenital absence of the anterior compartment muscle of both legs - a case report. Nihon Seikeigeka Gakkai Zasshi. 1986;60(5):485-93.

15. Stevens DB, Fink BA, Prevel C. Poland's syndrome in one identical twin. J Pediatr Orthop. 2000;20:392-5.

16. Franić-Ivanišević $M$, Franić $D$, Ivović $M$, Tančić-Gajić $M, M a-$ rina $\mathrm{Lj}$, Barac M, et al. Genetic etiology of primary premature ovarian insufficiency. Acta Clin Croat. 2016;55:629-35.https:// doi.org/10.20471/acc.2016.55.04.14 
Sažetak

\section{NEDOSTATAK DUGOG DLANSKOG MIŠIĆA KOD JEDNE OD JEDNOJAJČANIH BLIZANKINJA: PRIKAZ SLUČAJA}

\section{N. Vučinić, M. Erić, L. Grgurević, I. Dumić-Čule i N. Tičinović}

Dugi dlanski mišić je jedan od najvarijabilnijih mišića u tijelu, a često se koristi kao tetivni graft. Opisali smo razlike između jednog para jednojajčanih blizankinja u postojanju dugog dlanskog mišića, koje su slučajno identificirane tijekom ispitivanja prisustva/odsustva ovoga mišića u općoj populaciji. Kod jedne blizankinje dugi dlanski mišić je bio prisutan na obje podlaktice, dok je druga blizankinja bila bez ovoga mišića na objema podlakticama. Pretraživanjem dostupne literature nismo pronašli nijedan objavljen rad o razlikama u prisustvu ili odsustvu dugog dlanskog mišića kod blizanaca.

Ključne riječi: Tetive; Blizanci, jednojajčani; Mišic, skeletni; Podlaktica 